\title{
Abattoir waste use in livestock diets: Uganda's current situation
}

\author{
R. Mwesigwa ${ }^{1 \& 2^{*}}$, P.K. Migwi ${ }^{1}$, A.M. King'ori ${ }^{1}$ and P.A. Onjoro ${ }^{1}$ \\ Received 30 April 2020, Revised 17 June 2020, Accepted 20 June 2020, Published online 30 June 2020
}

\begin{abstract}
A B S T R A C T
In this study, we investigated the various ways slaughter wastes are utilized, problems encountered in order to give insights in future prospects of abattoir wastes as livestock feeds. A total of 100 abattoir workers were interviewed through semi-structured questionnaires covering Kampala, Wakiso and Mukono districts in Uganda. Results revealed that majority of abattoir work force were middle-aged adults between 30-45 years contributing $37 \%$ of total workers. There was a significant association between abattoir workers responses in relation to the proportion of livestock slaughtered (Chi square 147.55; $\mathrm{df}=2 ; \mathrm{p}<0.0001$ ) in the abattoirs. With reference to cattle, 1.06 and 1.01 more sheep and goats were slaughtered respectively in the dry season in comparison to the wet season. Blood was mostly disposed as animal feed ingredient (blood meal) by $40 \%$ of the respondents while rumen contents were mostly sold as manure by $59 \%$ of the respondents. Only $16 \%$ of the respondents processed rumen contents for livestock feeding. 92.3\% of bones were sold for dog feeding while $7.7 \%$ of bones were processed for livestock feed ingredients. Polythene bags were reported the biggest contaminants found in slaughter wastes. Stench from slaughter wastes contents was the biggest problem encountered with handling of waste products by (62\%) of the respondents. The handling of abattoir wastes was still rudimental at most abattoirs as envisaged by lack of proper handling facilities at the abattoirs. There is need for regular enforcements to ensure proper abattoir waste disposal mechanisms for enhanced livestock use.
\end{abstract}

Keywords: Regulation Awareness, Livestock Slaughtered, Slaughter Waste Contaminants.

${ }^{1}$ Faculty of Agriculture, Department of Animal Sciences, Egerton University, P.O Box 536 Egerton 20115, Kenya.

${ }^{2}$ National Agricultural Research Organization (NARO), Rwebitaba Zonal Agricultural Research and Development Institute, P.O BOX 96, Fort Portal, Uganda.

*Corresponding author's email: mwbobby247@gmail.com (R. Mwesigwa)

Cite this article as: Mwesigwa, R., Migwi, P.K., King'ori, A.M. and Onjoro, P.A. 2020. Abattoir waste use in livestock diets: Uganda's current situation. Int. J. Agril. Res. Innov. Tech. 10(1): 129-134. https://doi.org/10.3329/ijarit.v10i1.48105

\section{Introduction}

Abattoirs are designated licensed places for hygienic meat processing (Alonge, 2005). As a consequence of abattoir operations, several inedible byproducts that are unfit for direct human consumption both of organic and inorganic nature are generated (Zhang et al., 2017). These byproducts are potential animal feed ingredients if subjected to precautious further processing (Mwesigwa et al., 2020a). However, in most abattoir operations especially in developing countries the major aim is to maximize edible meat products for human consumption leaving the byproducts to the detriment of land degradation, environmental pollution and biodiversity devastation (Ojekunle and Lateef, 2017). Several measures have been undertaken by a number of regulatory bodies to ensure that abattoir byproducts are disposed in manner that adheres to environmental safety and health standards. In Uganda, these enforcements are mainly done by the local government veterinary officers (DVOs), public health officers (PHOs) and the national environmental management authority (NEMA). Despite the intergovernmental agency interventions to ensure abattoirs products remains safe to both consumers and the environment, there are concerns of laxity in implementation of these measures by both enforcement agencies and abattoir operators that has put consumers and environment at risk (Kyayesimira et al., 2019). This has not only left most abattoirs to operate at questionable healthy standards but also put livelihoods that depend on abattoir operations at great risk. In this study, we investigated abattoir wastes as source of livestock feeds, different ways the wastes are being utilized and challenges faced in order to give insight of the current state and future prospects of waste management in the central region of Uganda. 


\section{Methodology}

\section{Description of the study areas}

The study was carried out in the districts of Wakiso, Mukono and Kampala, which constitute part of central Uganda. Kampala, the capital city of Uganda is found $45 \mathrm{~km}$ north of the Equator at $0^{\circ} 19^{\prime} 6$ " N and $32^{\circ} 34^{\prime} 60^{\prime \prime} \mathrm{E}$ (Fig. 1). Wakiso district is located 20 kilometers northwest of Kampala, at oo $24 \mathrm{~N}, 3229 \mathrm{E}$ coordinates, while Mukono district is located $27 \mathrm{~km}$ from Kampala at $\mathrm{OO}^{\circ} 2 \mathrm{O}^{\prime} \mathrm{N}, 32^{\circ} 45^{\prime} \mathrm{E}$.

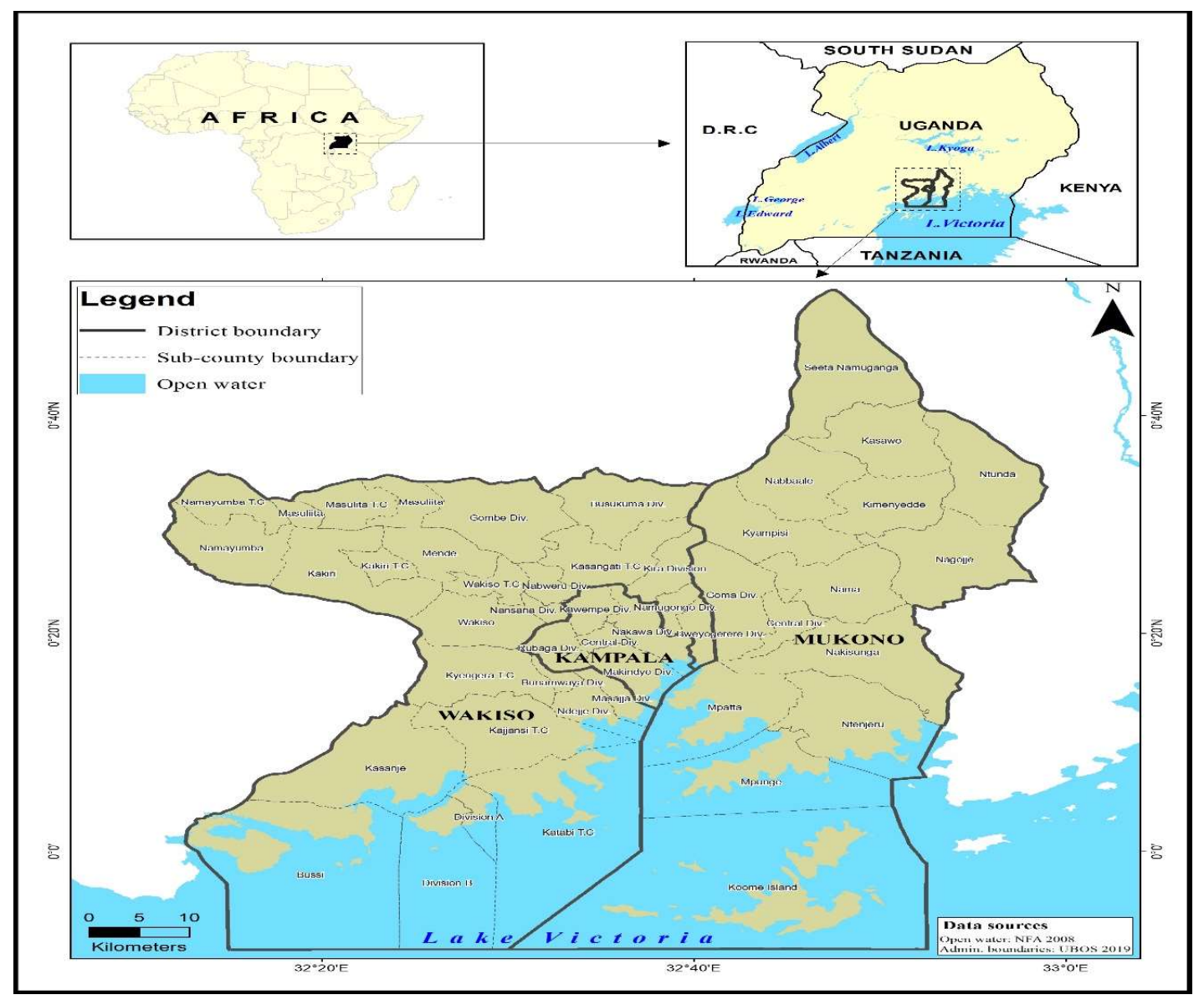

Fig. 1. Map showing the location of study area, source of the map (UBOS, 2018).

\section{Data collection}

Data was collected by means of interviews targeting abattoir operators/workers. The interviewees included a diverse category of people including veterinary doctors, health inspectors, abattoir chairpersons and people working in abattoirs. The sample size was determined according to formula by Yamane (1967).

$\mathrm{n}=N /(1+N *(e) 2$

Where, $\mathrm{n}$ is the sample size; $\mathrm{N}$ is the population size and $\mathrm{e}$, is the acceptable standard error; $\mathrm{e}=0.05$.

The sample size was calculated based on $95 \%$ confidence level. Considering a population of about 130 abattoir workers around the central districts in Uganda, a total of 100 participants were interviewed, 37 from Kampala, 37 from Wakiso and 26 from Mukono.
Both qualitative and quantitative data were collected using a structured questionnaire with both open and closed end questions. Qualitative data included, sex, marital, education status, type of animals slaughtered, abattoir waste utilization and potential constraints. On the other hand, quantitative data were family size, number and type of animals slaughter in wet and dry season.

\section{Data analysis}

Social demographic characteristics of the abattoir work force, whether farmers separated rumen contents from discarded carcasses and the various ways slaughter wastes were utilized were analyzed using descriptive statistics. Chi Square $\left(\chi^{2}\right)$ was used to test association between abattoir workers responses in relation to the proportion of livestock slaughtered and abattoir worker's awareness of the various regulations governing their operations. If any of the chi square cells was less than 5 , then fisher exact test statistics would be 
performed. Odds ratio (OR) was used to determine the strength of association between measured variables. The association between number and type of livestock slaughtered during the wet and dry season was modeled using multinomial logistic regression.

\section{Results and Discussion}

\section{Demographic characteristics of the respondents}

The majority of abattoir workers were middle aged adults between 30-45 years contributing $37 \%$ of total work force. This age bracket constitutes an energetically fit age group that is capable of executing the required intense abattoir duties as opposed to older people. People with within the age bracket of 60 to 90 years were the fewest in abattoir operations. Most abattoir workers have a Household (HH) size (1-5) people, a manageable $\mathrm{HH}$ number within the urban setting. This was in line with the findings of UBOS (2018) which revealed an average of 4.5 persons per household. Of the total abattoir respondents, the majority had attained at least secondary education, which concurred with the findings of Mwesigwa et al., (2020b). The majority of abattoir workers were married.

\section{Type of livestock slaughtered}

Table 1. Type of livestock slaughtered at the abattoirs.

\begin{tabular}{|l|l|l|l|l|l|l|}
\hline & Cattle & Goats & Sheep & Otherq & Chi Sq. & P-value \\
\hline Yes & $97^{\mathrm{a}}$ & $87^{\mathrm{b}}$ & $77^{\mathrm{c}}$ & $26^{\mathrm{d}}$ & $\mathbf{1 4 7 . 5 5}$ & $<0.0001^{*}$ \\
\hline No & $3^{\mathrm{d}}$ & $13^{\mathrm{c}}$ & $23^{\mathrm{b}}$ & $74^{\mathrm{a}}$ & & \\
\hline
\end{tabular}

* abcd superscripts indicate significant differences at $(P<0.05) .{ }^{q}$ (Camel and rabbits).

Livestock numbers slaughtered during the dry and wet season

slaughtered in the dry season in comparison to the wet season (Table 2).

The results showed that with reference to cattle, 1.06 and 1.01 more sheep and cattle were

Table 2. Odds estimate of livestock numbers slaughtered during dry and wet season.

\begin{tabular}{|l|l|l|l|c|}
\hline Reference & \multicolumn{1}{|c|}{ Effect } & Livestock & Point estimate & $\begin{array}{c}\text { 95\% Wald confidence } \\
\text { limits }\end{array}$ \\
\hline Cattle & Season: dry Vs wet & Sheep & 1.06 & $0.697-1.605$ \\
\hline & & Goat & 1.01 & $0.699-1.464$ \\
\hline Goat & & Sheep & 1.04 & $0.701-1.560$ \\
\hline
\end{tabular}

This is a result of livestock farmers selling most of their animals following dry spell. This practice enables farmers to remain with a small number of animals that can be supported by the available pastures (Dzavo et al., 2019). In reference to goats slaughtered in dry and wet season, 1.04 more and o.99 less sheep and cattle were slaughtered in the dry season compared to the wet season.

\section{Regulation awareness by abattoir operators/works}

There was significant association between awareness for regulatory bodies by abattoir operators (Chi square 15.91; df $=2$; p<0.0004). Most abattoir operators/workers were unaware of the regulations that govern their operations. This could be one of the reasons for the appalling working conditions at several abattoirs. 
Regulations of slaughter facilities not only aim to improve hygiene but also safe guards against the spread of diseases as well as workers from occupational health hazards (Mann, 1984). This calls for continued awareness by the responsible agencies (Cook, et al., 2017; Kyayesimira et al., 2019). Abattoir operators were more aware of the regulations given by Kampala city council authority (KCCA) than regulations from other agencies. This is because KCCA has been carrying out regular enforcements aimed at keeping Kampala the capital city of Uganda clean, through this campaign abattoirs operating within the jurisdiction of the city have also not been spared.

Table 3. Regulations awareness by abattoir operators.

\begin{tabular}{|c|c|c|c|c|c|}
\hline \multicolumn{6}{|c|}{ Regulatory bodies } \\
\hline Awareness & KCCA & NEMA & OTHER & Chi Sq. & P-value \\
\hline Aware (\%) & $34^{\mathrm{a}}$ & $11^{\mathrm{c}}$ & $21^{\mathrm{b}}$ & $15 \cdot 91$ & $<0.0004$ \\
\hline Not aware (\%) & $64^{c}$ & $88^{a}$ & $78^{b}$ & & \\
\hline
\end{tabular}

${ }^{a b c S u p e r s c r i p t s}$ with different letters indicate awareness significant differences at $(P<0.05) ;$ KCCA: Kampala city council regulations; NEMA: National environmental authority regulations OTHER: other regulations by district authorities.

The 2006 Meat ordinance act gives KCCA and local governments powers to carry out inspections and licensing of meat products. However, there have been laxity in implementation of these powers that has seen other government agencies like Uganda National Bureau of standards (UNBS) and KCCA sign a memorandum of understanding (MOU) with the aim of implementing joint operations and widen enforcements on abattoir to ensure compliance on hygiene standards (Daily Monitor, 2018).

\section{Separation of discarded carcasses from rumen contents}

In most abattoirs, discarded carcasses were separated from rumen contents (Fig. 2).

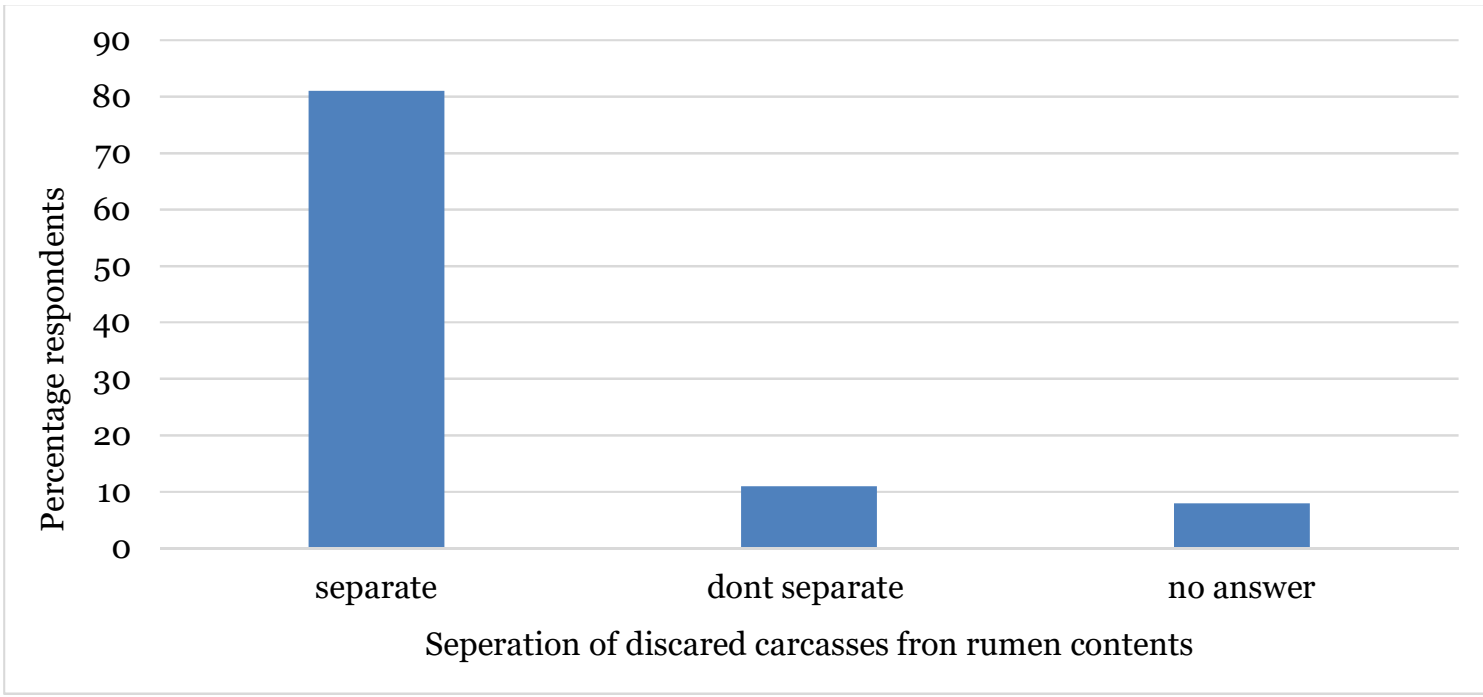

Fig. 2. Do you separate discarded carcasses from rumen contents?

How slaughter wastes are discarded or utilized

Table 4 shows the various ways how the different slaughter wastes were utilized/discarded in the sampled areas. Blood was mostly disposed as animal feed ingredient (blood meal) by $40 \%$ of the respondents while $37 \%$ of the respondents left it flow freely to drainage channels into the surrounding areas. This could be due to the increasing need of animal protein source in the feed industry. The blood was boiled and dried to produce blood meal. Abattoirs that were not producing blood meal, channeled the blood to surrounding areas along with the water while cleaning the abattoir, which becomes a serious sanitary problem (Aniebo et al., 2009). 
Table 4. How slaughter wastes are discarded/utilized.

\begin{tabular}{|l|c|c|c|}
\hline Slaughter waste discarding/utilization & Blood & Respondents \% & Bones \\
\hline Taken by drainage & 37 & 10 & - \\
\hline Taken by NWSC & 5 & - & - \\
\hline Incinerated & 11 & 8 & - \\
\hline Processed into animal feeds & 40 & 16 & 7.7 \\
\hline Dog food & 2 & - & - \\
\hline Manure & - & 59 & - \\
\hline Other & 5 & 7 & -3 \\
\hline
\end{tabular}

NWSC: National water and sewerage cooperation

Abattoirs that connected blood effluents to the national sewerage lines for further management were fewer $(5 \%)$ than those who incinerated the blood (11\%). This is because most abattoirs could not afford solid waste management charges by the national water and sewerage cooperation (NWSC), a Ugandan government agency in charge of water distribution and sewage management, this finding is in agreement with those of Tamenech and Tamirat (2017). Even the few abattoirs that were connected with the National sewage line rarely used it for their effluent management.

Rumen contents were mostly piled into pits and sold as manure for peri-urban agriculture by $59 \%$ of the respondents. This is in line with the findings by Darch et al. (2019) that fertilizers produced from abattoir wastes contribute to the plants mineral requirements for proper growth. Only $16 \%$ of the respondents sold dried rumen contents for livestock feeds. Rumen contents were first sun dried, sorted free of contaminants like polythene bags, metals and rags, then piled in sacks for sale. The sale of dried rumen contents was mainly done at Wankulukuku abattoir in Lubaga division one of the outskirt suburbs around Kampala, the
Capital City of Uganda. A bag of dried rumen content was sold at 20,000 Ugandan shillings (5.2 USD). The farmer intending to buy dried rumen contents would first place an order in advance. Dried rumen contents were mostly sold to poultry and pig farmers. The bones were mostly disposed as dog food and as a calcium source (bone meal) to feed manufactures. Promotion of abattoir waste use increases revenue of abattoir operators.

\section{Problems encountered with handling of slaughter wastes}

Stench from rumen contents was the biggest problem encountered by abattoir operators (62\%) followed by disposal costs (Fig. 3). This could be a result of lack of proper holding grounds. Most abattoirs lacked slaughter waste pre-treatment processes prior to waste disposal. This coupled with the length of stay before waste removal from the surrounding abattoir premises create ample time for decomposition of waste organic matter into volatile organic compounds such as ammonia and hydrogen sulphide, which creates intense undesirable off odors (Tamenech and Tamirat 2017).

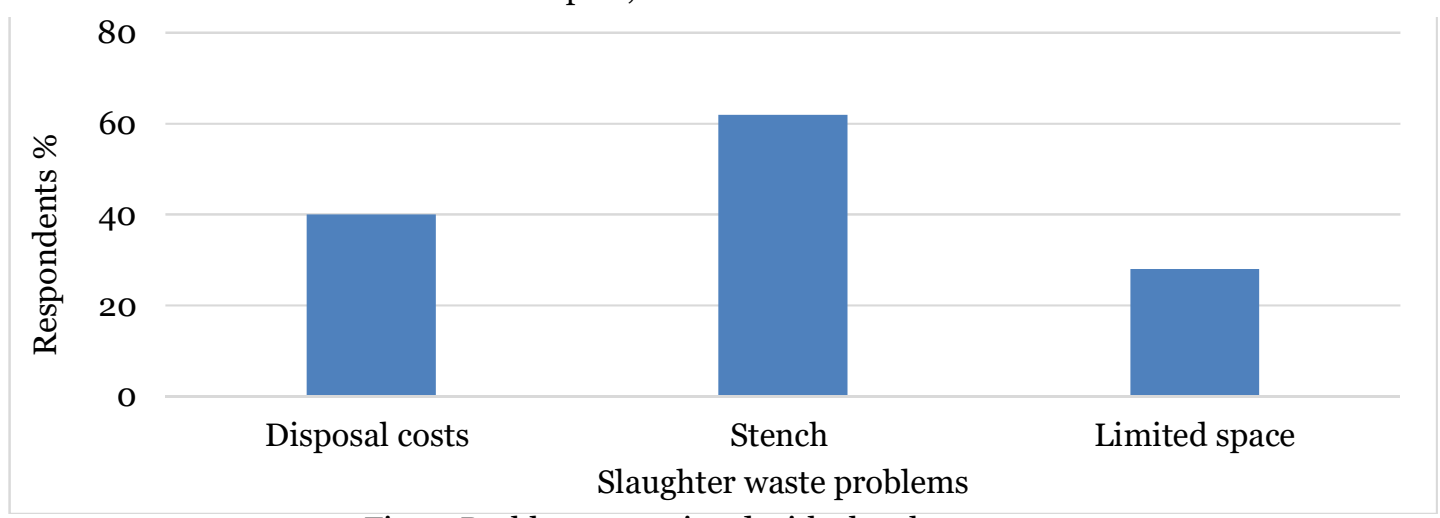

Fig. 3. Problems associated with slaughter wastes.

Contaminants found in slaughter wastes

Polythene bags were reported the biggest contaminants found in slaughter wastes (Table 5). Prevalence of polythene bags in slaughter wastes was a result of improper disposal of polythene bags by people, which eventually found their way into the environment from where they are eaten along following grazing (Aurah, 2013). Ingestion of polythene bags by livestock could be one of the reasons for their underperformance as ingested plastic bags leads to bloat and poor appetite
(Nandwa, 2014). Among the other contaminants included thorns, sodom apple and tree seeds. Abattoir workers also reported being injured by sharp objects (thorns and metals) when extruding rumen contents which eventually led to hand skin itching. This can further lead to meat contamination since most abattoir workers hardly put on hand gloves in developing countries (Mann, 1984). The presence of various contaminants in livestock wastes presents a potential health hazard to both livestock and the consumers. 
Table 5. Contaminants found in slaughter wastes.

\begin{tabular}{|l|c|c|c|}
\hline Contaminants (\%) & Cattle & Goats & Sheep \\
\hline Polythene bags & 51 & 30 & 11 \\
\hline Metals & 26 & 34 & 5 \\
\hline Rags & 3 & 15 & 13 \\
\hline Other & 10 & 2 & 23 \\
\hline
\end{tabular}

\section{Conclusion}

Among the abattoir wastes, blood was the mostly used in animal feeds as blood meal. Most abattoirs still disposed wastes in an environmentally unfriendly manner, which predisposes the public to several health epidemics. There is need for increased government regulation aimed at increasing abattoir hygiene for public safety in line with confines of the law.

\section{Acknowledgements}

We appreciate the financial support from the Centre of Excellence in Sustainable Agriculture and Agribusiness Management (CESAAM) at Egerton University, Kenya.

\section{References}

Alonge, D.O. 2005. Meat and Milk Hygiene in the Tropics. Farmose Press, Ibadan, Nigeria. pp. 77-86.

Aniebo, A.O., Wekh, S.N. and Okoli, I.C. 2009. Abattoir blood waste generation in River state and its environmental implications in the Niger Delta. Toxicol. Environ. Chem. 91: 619-625.

https://doi.org/10.1080/02772240802343404

Aurah, M.C. 2013. Assessment of extent to which plastic bag waste management methods used in Nairobi City promote sustainability. American J. Environ. Prot. 1: 96 - 101. https://doi.org/10.12691/env-1-4-4

Cook, E.A.J., de Glanville, W.A. and Thomas, L.F. 2017. Working conditions and public health risks in slaughterhouses in western Kenya. BMC Public Health. 17: 14. https://doi.org/10.1186/s12889-016-3923-y

Daily Monitor. 2018. UNBS is enforcing meat standards to protect consumers' health and safety, Wednesday January 24, 2018. https://www.monitor.co.ug/OpEd/Commentary/ UNBS-meat-standardsconsumers-healthsafety/689364-4275374-fg6uwez/index.html

Darch, T., Dunn, R.M., Guy, A., Hawkins, J.M.B. and Ash, M. 2019. Fertilizer produced from abattoir waste can contribute to phosphorus sustainability, and biofortify crops with minerals. PLOS ONE. 14(9): e0221647. https://doi.org/10.1371/journal.pone. 0221647

Dzavo, T., Zindove, T.J. and Dhliwayo, M. 2019. Effects of drought on cattle production in sub-tropical environments. Trop. Animal Health Prod. 51: 669-675.

https://doi.org/10.1007/s11250-018-1741-1
Kyayesimira, J., Wangalwa, R., Kagoro, R.G., Lejju, J.B., Joseph, W., Matofari, J.W. and Andama, M. 2019. Causes of losses and the economic loss estimates at post-harvest handling points along the beef value chain in Uganda. J. Agril. Ext. Rural Dev. 11: 176-183. https://doi.org/10.5897/JAERD2019.1074

Mann, I. 1984. Guidelines on small slaughterhouses and meat hygiene in developing countries. Eds. Koulikovskii A, and Matyas, Z. Geneva: World Health Organization. 106p.

https://apps.who.int/iris/handle/10665/66404

Mwesigwa, R., Migwi, P.K., King'ori, A.M. and Onjoro, P.A. 2020b. Extent of rumen contents use in livestock diets among farmers in Uganda. African J. Agril. Res. 15: 248-255. https://doi.org/10.5897/AJAR2019.14652

Mwesigwa, R., Migwi, P.K., King’ori, A.M., Onjoro, P.A., Odero-Waitiuh, J., Xiangyu, H. and Zhu, W. 2020a. Improvement of growth performance and meat sensory attributes through use of dried goat rumen contents in broiler diets. African J. Agril. Res. 15: 446456. https://doi.org/10.5897/AJAR2020.14743

Nandwa, P. 2014. Harmful effects of plastic wastes on livestock: Laikipia Rural Voices. https://plus.google.com/1135655519746 63752218.

Ojekunle, O.Z. and Lateef, S.T. 2017. Environmental impact of abattoir waste discharge on the quality of surface water and ground water in abeokuta. J. Environ. Anal. Toxicol. 7(5): 509.

https://doi.org/10.4172/2161-0525.1000509

Tamenech, B. and Tamirat, H. 2017. Review of abattoir waste management. Glob. Vet. 19: 517-524.

UBOS. 2018. Uganda National Bureau of Statistics (UBOS), Statistical abstract. 315p. https://www.ubos.org/wpcontent/uploads/publications/05_2019STATIST ICAL_ABSTRACT_2018.pdf

Yamane, T. 1967. Statistics, An introductory analysis, (2 ${ }^{\text {nd }}$ Ed.). New York: Harper and Row. 919p.

Zhang, B., Tian, H., Lu, C., Dangal, S.R.S., Yang, J. and Pan, S. 2017. Global manure nitrogen production and application in cropland during 1860-2014: A 5 arcmin gridded global dataset for earth system modelling. Earth Syst. Sci. Data. 9: 667-678. https://doi.org/10.5194/essd-9-667-2017 